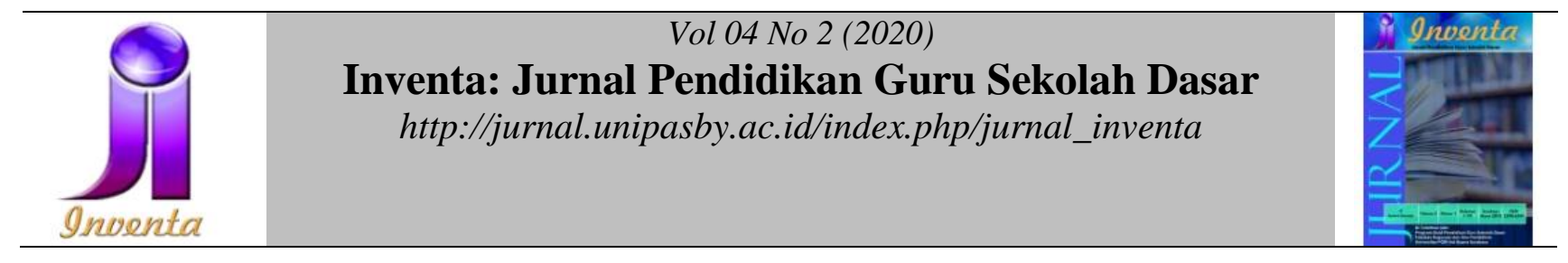

\title{
Peningkatan Hasil Belajar Bangun Ruang Melalui Metode Duti Duta (Two Stay Two Stray) Siswa Kelas IV SDN Buncitan Kecamatan Sedati Kabupaten Sidoarjo
}

\author{
Ahmad Zaini \\ SDN Buncitan Sedati Sidoarjo
}

Corresponding author email: zain.sidoarjo@gmail.com

\begin{tabular}{ll}
\hline & Abstrak \\
\hline Kata Kunci: & Penelitian ini dilatarbelakangi oleh fakta bahwa hasil belajar siswa kurang \\
pembelajaran & optimal. Tujuan dari penelitian ini adalah untuk meningkatkan hasil belajar \\
kooperatif, Teknik Two & siswa melalui metode Two Stay Two Stray dengan materi pembelajaran \\
Stay Two Stray, bangun & bangun ruang pada siswa kelas IV SD Negeri Buncitan Sedati Sidoarjo. \\
ruang, sekolah dasar & Penelitian ini menggunakan metode pembelajaran Two Stay Two Stray \\
& sehingga siswa dapat termotivasi untuk belajar. Teori-teori pembelajaran \\
& secara umum lebih tepat jika diajarkan dengan metode pembelajaran \\
& kooperatif, dimana siswa bekerja sama dengan siswa lain dalam berpikir \\
& secara mandiri untuk menyelesaikan masalah yang ada. Hasil penelitian \\
& tentang penerapan pembelajaran kooperatif Two Stay Two Stray materi \\
& bangun ruang kelas IV SDN Buncitan pada observasi awal dengan persentase \\
& $43,8 \%$ dalam penguasaan pembelajaran. Siklus 1 menunjukkan bahwa hasil \\
& pembelajaran nilai rata-rata kelas 71,8 dengan persentase penguasaan \\
pembelajaran $68,8 \%$, kemudian meningkat di siklus 2 dengan nilai rata-rata \\
secara klasikal 76,1 dengan persentase ketuntasan 78,1\%. Kesimpulan dari \\
penelitian ini bahwa penggunaan metode pembelajaran kooperatif Two Stay \\
Two Stray dapat meningkatkan hasil belajar siswa pada materi bangun ruang \\
kelas IV SDN Buncitan Sedati Sidoarjo.
\end{tabular}

Keyword:

Cooperative Learning, Two Stay Two Stray Tecnique, Geometry, Elementary school

\section{Abstract:}

This research is motivated by the fact that the learning outcomes of students. The purpose of this research is to improve the learning outcomes of students through methods Two Stay Two Stray the subject matter of waking up space on the fourth grade students of SD Negeri Buncitan Sedati Sidoarjo. This study uses learning methods Two Stay Two Stray is applied so that students can be motivated to learn The general procedural theories more appropriate if taught with cooperative learning methods, one where students work together with other students in thinking independently to solve existing problems. The results of research on the application of cooperative learning Two Stay Two Stray in wake classroom materials IV SDN Buncitan on preliminary observations with a percentage of $43,8 \%$ mastery learning. Around 1 shows that the average grade 71,8 with a percentage of $68,8 \%$ mastery learning, then increasing in around 2 the average value of 76,1 students into a class with a percentage of $78,1 \%$ completeness. The conclusion of this study that the use of cooperative learning methods Two Stay Two Stray can improve the learning outcomes of student grade fourth of State Elementary school Buncitan Sedati Sidoarjo 
Pendahuluan

Standar Kompetensi dan Kompetensi Dasar matematika di Sekolah Dasar disusun sebagai landasan pembelajaran untuk mengembangkan kemampuan siswa. Selain itu dimaksudkan pula untuk mengembangkan kemampuan menggunakan matematika dalam pemecahan masalah sehari-hari. Oleh karena itu matematika perlu diberikan pada siswa sejak dini di Sekolah Dasar.

Sardiman (2006) dalam pengertian luas mengemukakan bahwa belajar dapat diartikan sebagai kegiatan psiko-fisik menuju ke perkembangan pribadi seutuhnya. Kemudian dalam arti sempit, belajar dimaksudkan sebagai usaha penguasaan materi ilmu pengetahuan yang merupakan sebagian kegiatan menuju terbentuknya kepribadian seutuhnya.

Matematika merupakan ilmu pasti yang keberadaannya sangat berguna bahkan kemanfaatnnya hampir dalam seluruh aspek kehidupan manusia yang di dalamnya mengembangkan daya pikir manusia. Bersifat logis, berjenjang dari yang paling mudah hingga yang paling rumit yang memiliki pengaruh besar dalam perkembangan ilmu pengetahuan dan teknologi.
Matematika selama ini merupakan pelajaran yang menjadi momok dan bahkan menganggap matematika menjadi suatu yang menakutkan tersendiri bagi siswa.

Logika matematika tidak dapat ditransfer secara utuh dari pikiran guru ke pikiran siswa tetapi harus dibangun dalam pikiran siswa sendiri sebagai usaha keras siswa untuk mengorganisasi pengalamanpengalamannya dalam hubungannya dengan skema atau stuktur mental yang ada sebelumnya. Permasalahan ini menyebabkan rendahnya pemahaman siswa terhadap soal cerita pada mata pelajaran matematika, yang turut berperan dalam mempengaruhi rendahnya hasil belajar siswa tersebut.

\section{Kajian Teori}

Menurut Dimyati dan Mudjiono (2009) Hasil belajar merupakan hal yang dapat dipandang dari dua sisi yaitu dari sisi siswa dan dari sisi guru. Dari sisi siswa, hasil belajar merupakan tingkat perkembangan mental yang lebih baik bila dibandingkan pada saat sebelum belajar. Tingkat perkembangan mental tersebut terwujud pada jenisjenis ranah kognitif, afektif, dan psikomotor. Sedangkan dari sisi guru, 
hasil belajar merupakan saat terselesaikannya bahan pelajaran.

Perkembangan pendidikan dewasa ini menuntut siswa agar mampu menjawab tantangan global dimana siswa tidak hanya cerdas dalam ranah kognitif saja tanpa dilandasi dengan keterampilan hidup dan keluasan hati. Oleh karenanya dalam pembelajaran perlu membiasakan pada siswa Sekolah Dasar tentang pembelajaran melalui pendekatan keterampilan proses, yaitu pendekatan dalam proses pembelajaran yang menekankan pembentukan keterampilan untuk memperoleh pengetahuan dan mengkomunikasikan pemerolehannya. Hal ini tentunya dalam pembelajaran diperlukan suatu metode pembelajaran yang aktif, inovatif, kreatif, efektif, menyenagkan dan diharapkan siswa mampu bekerja sama dengan yang lain dalam pembelajaran yang dapat diwujudkan dalam model kooperatif tipe Duti Duta (Dua Tinggal Dua Tamu).

Pembelajaran kooperatif akan menghasilkan prestasi belajar yang lebih tinggi karena adanya perenungan pemikiran secara bersama-sama yang terdiri dari beberapa daya pemikiran siswa. Interaksi sosial dan perbedaan antar sesama manusia yang hakiki apabila tidak dikelola dengan baik akan menghasilkan perselisihan dan gesekan antara siswa. Oleh karenanya pembelajaran kooperatif menitikberatkan pada pengelompokan siswa sehingga sehingga akan tercipta hubungan antar siswa yang positif yang didalamnya menjelaskan kepada teman sekelompoknya, menghargai pendapat teman, berdiskusi dengan teratur, siswa yang pandai membantu yang lebih lemah sehingga terwujud suasana belajar yang kuat.

Pembelajaran kooperatif akan menghasilkan prestasi belajar yang lebih tinggi karena adanya perenungan pemikiran secara bersama-sama yang terdiri dari beberapa daya pemikiran siswa. Interaksi sosial dan perbedaan antar sesama manusia yang hakiki apabila tidak dikelola dengan baik akan menghasilkan perselisihan dan gesekan antara siswa.

Pembelajaran kooperatif two stay two stray adalah teknik pembelajaran yang dapat mendorong anggota kelompok untuk memperoleh konsep secara mendalam melalui pemberian peran pada siswa. Struktur dua tinggal dua tamu memberi kesempatan kepada kelompok untuk membagikan hasil dan informasi dengan kelompok lain. (Lie, 2008).

Model pembelajaran ini dapat digunakan dalam semua mata pelajaran dan semua tingkatan usia siswa Sekolah 
Dasar khususnya di SD Negeri Buncitan Kecamatan Sedati Kabupaten Sidoarjo.

Suatu model pembelajaran yang dipilih pasti memiliki kekurangan dan kelebihan. Kelebihan dari model pembelajaran Kooperatif teknik Two Stay Two Stray adalah: (1) dapat diterapkan pada semua kelas/tingkatan;

kecenderungan belajar siswa menjadi lebih bermakna; (3) lebih berorientasi pada keaktifan; 4) diharapkan siswa akan berani mengungkapkan pendapatnya; (5) menambah kekompakan dan rasa percaya diri siswa; (6) kemampuan berbicara siswa dapat ditingkatkan; (7) membantu meningkatkan minat dan prestasi belajar. Pembelajaran kooperatif tipe Two Stay Two Stray ini akan mengurangi kegiatan ceramah yang berlebihan dan sering mendominasi dalam peroses pembelajaran di kelas. Siswa dituntut aktif untuk menemukan informasi sendiri dan siswa yang lain memiliki tanggung jawab untuk berbagi dengan lainnya.

Siswa di kelas IV SDN Buncitan Kecamatan Sedati berjumlah 32 siswa dengan 17 siswa perempuan dan 15 siswa laki-laki, dari data tersebut terlihat bahwa siswa yang cukup besar membuat suasana kelas selalu ramai dan sulit dikendalikan. Sehingga guru harus pandai memilih model pembelajaran untuk menarik perhatian dan minat belajar siswa. Pada materi bangun ruang mengalami kesulitan, ini terbukti dari hasil observasi awal bahwa siswa yang mencapai Kriteria Ketuntasan Minimal (KKM) yaitu mencapai 43,8 \% dengan rincian 18 siswa tidak tuntas dan 14 siswa tidak tidak tuntas atau tidak mencapai KKM. Disamping itu siswa kurang aktif dalam pembelajaran, tidak berani menampilkan hasil belajar dengan kelompok di depan kelas sehingga mengakibatkan hasil belajar materi bangun ruang peserta didk kelas IV di SDN Buncitan masih rendah.

Dari uraian di atas maka peneliti melakukan Penelitian Tindakan Kelas yang berjudul "Meningkatkan Hasil Belajar Bangun Ruang Melalui Metode Duti Duta (Two Stay Two Stray) pada sisw kelas IV SDN Buncitan Kecamatan Sedati Kabupaten Sidoarjo".

\section{Metode Penelitian}

Penelitian ini merupakan penelitian tindakan kelas (Classroom Action Research). Penelitian tindakan kelas adalah kajian sistemik dari upaya perbaikan praktek pendidikan oleh sekelompok guru dengan melakukan tindakan-tindakan dalam pembelajaran, berdasarkan refleksi sekelompok guru mengenai hasil dari tindakan-tindakan 
tersebut. (Rochiati Wiriaatmadja, 2007). Penelitian tindakan kelas ini berfokus pada penyempurnaan atau peningkatan proses dan praktis pembelajaran. PTK dilakukan dengan tujuan memperbaiki mutu pembelajaran di kelas dengan berfokus pada kelas atau pada proses pembelajaran yang terjadi di kelas dengan ciri khusus adanya tindakan yang nyata.

Setiap siklus terdiri dari kegiatan planning (rencana), action (tindakan), observation (pengamatan), dan reflection (refleksi). Langkah pada siklus berikutnya adalah perncanaan yang sudah direvisi, tindakan, pengamatan, dan refleksi. Sebelum dilakukan kegiatan pada siklus 1 dilakukan tindakan pendahuluan yang berupa identifikasi permasalahan. Tindakan pendahuluan ini dimaksudkan untuk mengetahui permasalahanpermasalahan yang terjadi.

Rancangan penelitian ini dapat dijelaskan sebagai berikut.

1). Perencanaan, sebelum mengadakan penelitian peneliti menyusun rumusan masalah, tujuan dan membuat rencana tindakan, termasuk di dalamnya instrumen penelitian dan perangkat pembelajaran. 2). Kegiatan dan pengamatan, meliputi tindakan yang dilakukan oleh peneliti sebagai upaya membangun pemahaman konsep siswa serta mengamati hasil atau dampak dari diterapkannya metode pembelajaran model belajar tuntas. 3). Refleksi, peneliti mengkaji, melihat dan mempertimbangkan hasil atau dampak dari tindakan yang dilakukan berdasarkan lembar pengamatan yang diisi oleh pengamat. 4). Rancangan/rencana yang direvisi, berdasarkan hasil refleksi dari pengamat membuat rancangan yang direvsi untuk dilaksanakan pada siklus berikutnya.

Trianto (2010) menjelaskan bahwa berdasarkan KTSP penentuan ketuntasan belajar ditentukan sendiri oleh masingmasing sekolah yang dikenal dengan istilah kriteria ketuntasan minimal, dengan berpedoman pada tiga pertimbangan, yaitu: kemampan setiap peserta didik berbeda-beda, fasilitas (sarana) setiap sekolah berbeda, dan daya dukung setiap sekolah berbeda.

Data yang dianalisis secara deskriptif kualitatif adalah data hasil observasi pembelajaran, sedangkan data yang dianalisis secara deskriptif kuantitatif adalah data tentang kemampuan dalam mengerjakan soal bangun ruang yang dinyatakan dengan nilai (score) yang dicapai siswa dari hasil tes. Hasil rata-rata tes siswa dapat dicari dengan rumus:

Untuk menghitung persentase ketuntasan belajar digunakan rumus 
sebagai berikut: dalam kelas mencapai $75 \%$ atau lebih $p=\frac{\sum \text { siswa tuntas }}{\sum \text { Siswa }} \times 100 \%$ siswa mencapai ketuntasan belajar.

(Depdiknas, 2005:15)

Dari data yang diperoleh kemudian diolah untuk menentukan berhasil dan tidaknya proses pembelajaran yang telah dilakukan di kelas.

Ketuntasan Hasil Belajar Siklus 1-II

Ketuntasan belajar (daya serap) merupakan pencapaian taraf penguasaan minimal yang telah ditetapkan guru dalam tujuan pembelajaran setiap satuan pelajaran. Ketuntasan belajar dapat dianalisis dari dua segi yaitu ketuntasan belajar pada siswa dan ketuntasan belajar pada materi pelajaran/tujuan pembelajaran, keduanya dapat dianalisis secara perorangan atau perkelas siswa. Kriteria ketuntasan menunjukkan persentase tingkat pencapaian kompetensi sehingga dinyatakan dengan angka maksimum 100.

Angka maksimum 100 merupakan kriteria ketuntasan ideal. Satuan pendidikan dapat memulai dari kriteria ketuntasan minimal di bawah target nasional kemudian ditingkatkan secara bertahap. Siswa dikatakan tuntas belajar apabila dalam kelas mencapai nilai 70 atau lebih. Sedangkan ketuntasan kelas apabila

\section{Hasil Dan Pembahasan}

Hasil penelitian pada siklus 1 diperoleh nilai rata-rata kelas prestasi hasil belajar siswa yaitu 71,8. Data ini menunjukkan bahwa ada 10 siswa $(31,2 \%)$ di bawah KKM dan 22 siswa di atas KKM $(68,8 \%)$. Dengan hasil ini masih banyak siswa yang tidak tuntas sehingga ketuntasan belajar pada siklus 1 mencapai $68,8 \%$. Hasil tersebut dapat dilihat pada Gambar 1.

Gambar 1. Hasil Belajar siswa

Walaupun hasil tes siklus 1 menunjukkan peningkatan, tetapi karena belum mencapai indikator ketuntasan belajar maka penelitian dilanjutkan pada siklus 2 .

Hasil penelitian pada siklus 2 diperoleh nilai rata-rata kelas yaitu 76,1 dengan uraian bahwa sebanyak 25 siswa $(78,1 \%)$ tuntas belajar dan 7 siswa $(21,9 \%)$ tidak tuntas dalam belajar.

Hasil penelitian pada siklus 1 dan 2 dapat dijelaskan pada tabel 1 .

Tabel 1. Hasil belajar siswa yang diperoleh pada Siklus 1 dan Siklus 2 


\begin{tabular}{|c|c|c|c|}
\hline \multirow[t]{2}{*}{ No. } & \multirow[t]{2}{*}{ Uraian } & \multicolumn{2}{|c|}{ Siklus } \\
\hline & & I & II \\
\hline 1 & $\begin{array}{l}\text { Jumlah siswa } \\
\text { yang tuntas ( } \geq \\
70) \text {. }\end{array}$ & 22 & 25 \\
\hline 2 & $\begin{array}{ll}\text { Siswa yang } \\
\text { tidak tuntas }(<70) \text {. }\end{array}$ & 10 & 7 \\
\hline 3 & $\begin{array}{l}\text { Persentase siswa } \\
\text { tuntas belajar. }\end{array}$ & $68,8 \%$ & $78,1 \%$ \\
\hline 4 & $\begin{array}{l}\text { Persentase siswa } \\
\text { tidak tuntas } \\
\text { belajar. }\end{array}$ & $31,2 \%$ & $21,9 \%$ \\
\hline
\end{tabular}

Data hasil pembelajaran ini menunjukkan bahwa pembelajaran dengan metode Duti Duta meningkat dengan siswa telah tuntas dalam pembelajaran mengalami peningkatan lebih dari $10 \%$. Hasil ini juga telah sesuai dengan keinginan peneliti bahwa tindakan pembelajaran dinyatakan berhasil apabila $75 \%$ atau lebih telah menguasai ketuntasan minimal atau mencapai KKM.

Dari hasil analisis tersebut, maka dapat dibuat pembahasan penelitian yang dirangkum pada uraian berikut ini:

1). Kemajuan belajar siswa dalam implementasi metode Duti Duta Berdasarkan hasil penelitian dengan impelementasi metode Duti Duta kemajuan belajar siswa terlihat meningkat dalam pemahaman materi dan kenginan siswa untuk mengetahui materi lebih lanjut. Hal ini dapat dilihat dalam tabel rekapitulasi kemajuan belajar yang didapat dari jurnal siswa selama dua kali siklus sebagai berikut. 2). Hasil belajar dalam implementasi metode Duti Duta. Hasil belajar berdasarkan kemampuan kognitif dalam penelitian ini diperoleh dari pos tes pada setiap akhir pembelajaran. Berdasarkan hasil yang diperoleh dapat diuraikan bahwa hasil belajar dalam pelaksanaan pembelajaran di kelas IV pada siklus 1 terdapat 10 siswa $(31,2 \%)$ yang belum memenuhi KKM (Kriteria Ketuntasan Minimal) dan yang mencapai KKM sebesar 68,8\%. Nilai tersebut diperoleh dari rata-rata kelas yaitu jumlah keseluruhan nilai yang didapat siswa dalam satu kelas dibagi banyaknya siswa $(2298: 32=71,8)$. Pada siklus 2 ada 7 siswa yang belum memenuhi SKM dan mencapai daya serap sebesar 78,1\%.

Hasil observasi berupa tes pada siklus 2 digolongkan dalam kategori baik. Oleh karena itu, peneliti menyimpulkan bahwa ada peningkatan kemampuan siswa kelas IV SD Negeri Buncitan Kecamatan Sedati Kabupaten Sidoarjo dalam menyebutkan sifat-sifat bangun ruang sederhana, seperti balok, kubus, tabung, kerucut, dan bola. Keberhasilan tersebut disebabkan peneliti menggunakan metode Duti Duta Itwo Stay Two Stray) dalam kegiatan pembelajaran.

Dapat diuraikan bahwa selama dua kali siklus daya serap kelas IV mengalami peningkatan dan jumlah siswa yang 
berhasil memenuhi Kriteria Ketuntasan Minimal (KKM) juga meningkat, sehingga diperoleh persentase ketuntaan belajar kelas IV SDN Buncitan sebesar $78,1 \%$.

\section{Kesimpulan}

Berdasarkan hasil analisis data dapat disimpulkan bahwa penerapan metode Duti Duta (Two Stay Two Stray) dapat meningkatkan hasil belajar bangun ruang pada siswa kelas IV SDN Buncitan Kecamatan Sedati Kabupaten Sidoarjo. Hal ini dapat dibuktikan dari ketuntasan klasikal pada saat observasi awal yaitu $43,8 \%$ pada siklus 1 meningkat menjadi 68,8\%. Hasil tersebut lebih meningkat pada siklus 2 yaitu $78,1 \%$.

\section{SARAN}

1). Guru hendaknya lebih memperhatikan faktor-faktor yang dapat meningkatkan hasil belajar. 2). Guru seharusnya menerapkan metode pembelajaran yang efektif untuk meningkatkan hasil belajar.3). Guru seharusnya berpijak pada komponen strategi-strategi pembelajaran. 4). Guru seharusnya secara aktif menggali sumber-sumber metode pembelajaran. 5). Dinas terkait dan manajemen sekolah hendaknya mempunyai komitmen tinggi dalam meningkatkan mutu pendidikan.

\section{Daftar Pustaka}

Depdiknas, (2005). Matematika. Jakarta: Dirjen Dikti Depdiknas.

Dimyati dan Mudjiono. (2009). Belajar dan Pembelajaran. Jakarta: Rineka Cipta.

Hamalik, Oemar. (1982). Ciri-Ciri Belajar. Jakarta: Depdikbud.

Hamalik, Oemar. (2001). Proses Belajar Mengajar. Jakarta: Bumi Aksara

Lie, Anita. (2008). Cooperative Learning. Jakarta: PT Gramedia Widiasarana.

Rochiati, Wiriaatmaja. (2006). Penelitian Tindakan Kelas. Jakarta: PT. Remaja.

Trianto. 2010. Mendesain Model Pembelajaran Inovatif-Progresif: Konsep, Landasan, dan Implementasinya pada Kurikulum Tingkat Satuan Pendidikan (KTSP). Jakarta: Kencana Prenada Media Group. 